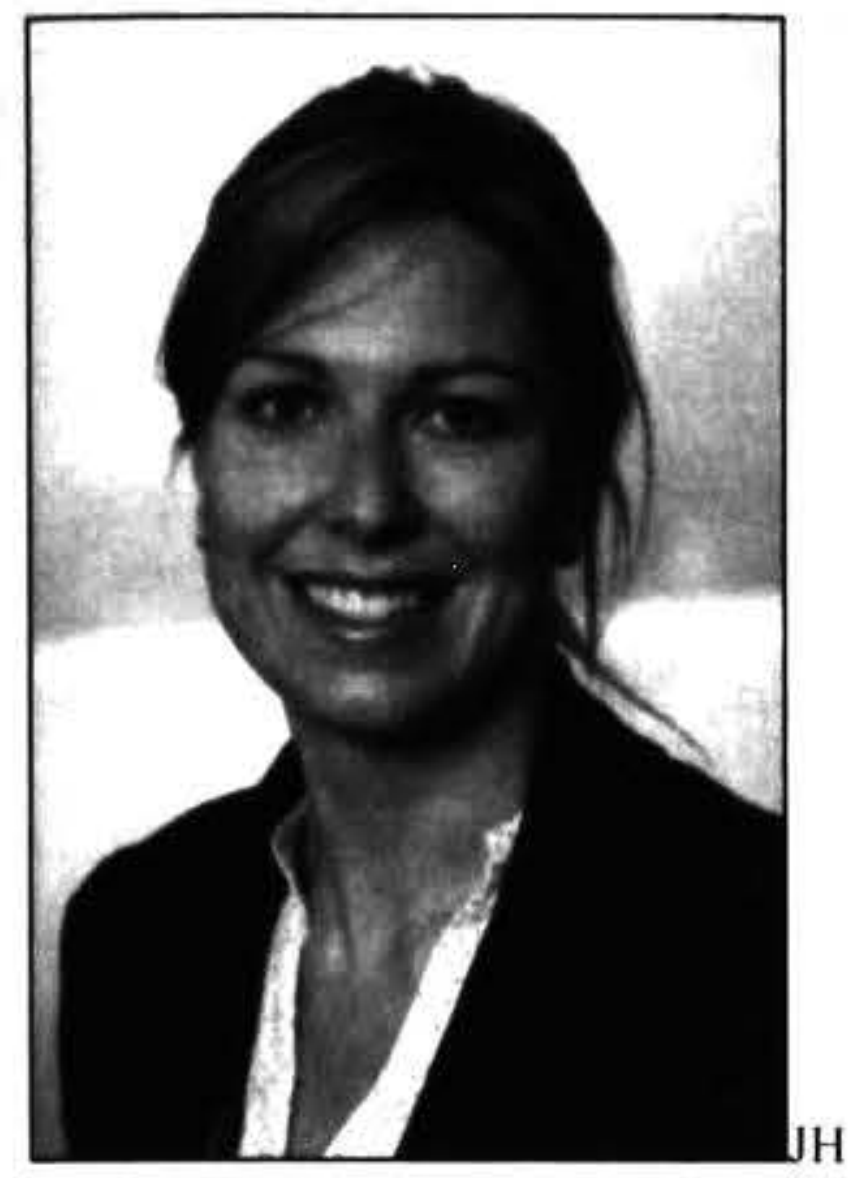

\section{RECOGNITION AND REWARDS: RESEARCH AND RESULTS OF A SYSTEM IN A NEW ZEALAND ORGANISATION}

\author{
Jessica Harvey \\ Heinz Wattie 's Ltd, Hastings
}

\author{
Robbie Field \\ Faculty of Business and Computing, \\ Eastern Institute of Technology, Napier
}

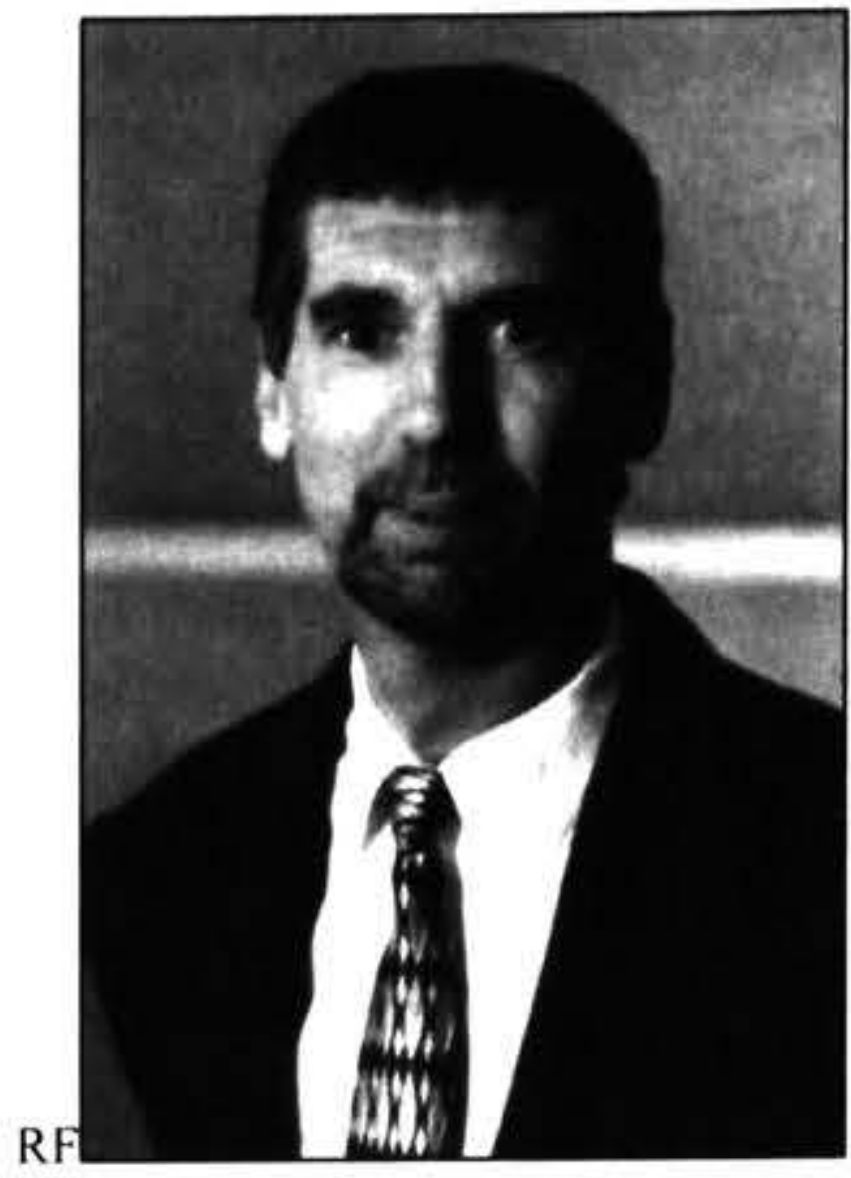

The challenge for employers is to identify and implement recognition and rewards programmes that are not complex. yet effective, and which support a working environment that improves motivation and staff morale, whilst at the same time impacting positively on organisational performance. Research into recognition and rewards programmes would indicate that there are a number of options available and that successful programmes and current approaches need to include certain fundamental requirements. This paper investigates and provides the results of feedback from staff surveved in relation to an existing recognition and rewards programme at a large food-manufacturing organisation in New Zealand with a view towards improving the current system. Based on the research undertaken changes were made to the existing programme and a revised recognition and rewards system was implemented. Emplovees were again surveyed within a year of the revised system being introduced in order to assess the effectiveness of the changed programme. The authors purport that initial results of the surver would indicate that most recognition related variables have improved with the changed programme and that the revised sistem can be regarded as successful.

\section{Introduction}

To facilitate desired employee behaviours with the aim of ultimately assisting in achieving business objectives and organisational effectiveness, a large food manufacturing organisation in New Zealand commissioned extensive research into recognition and reward systems. Research was undertaken within current company recognition systems, benchmark organisations and through surveying managers and employees. It was fundamental to the organisation that the system promoted consistency, was easy to use, recognised all outstanding efforts, was unforced and spontaneous and ultimately low cost. A revised recognition system was designed and implemented based on these principles and the research undertaken. Employees were surveyed six months after the revised rewards/recognition system was implemented and the results indicated that there has been an overall improvement in the areas of recognition and rewards, performance and leadership.

\section{Literature Review}

Recognition programmes are typically a form of individual or work-group incentive that is outside the normal remuneration system (including wages, salary and bonuses). Wages and salary are usually the fixed compensation an individual receives for undertaking a job. Bonus systems also differ in that bonuses are a discretionary reward provided after the achievement of a goal (making it reactive).

Stone (2002) categories recognition programmes as an incentive, which is a pro-active measure that focuses on a person's behaviour by establishing performance objectives and rewarding the achievement of these objectives. O'Neill (cited in Wiesner \& Millett, 2003) further highlights this by classing fixed pay as an "input" reward which aims to appropriately recognise the individual human capital value of the person to the firm. Alternatively short-term incentives, such as recognition awards are "output" rewards that aim to reward people for their role in delivering outcomes to the company.

Increasingly organisations are looking towards nontraditional recognition and rewards systems to retain and motivate employees. An effective recognition and rewards programme can achieve this by creating a positive environment that encourages workers to thrive (Bursch, 1999). This is consistent with research of recognition systems within organisations featuring in New Zealand's Unlimited Top 20 Best Places to Work (2003), which all place a high level of respect and trust towards employees. Additionally, Bell (2004: 16) stated that "business benefits as these basic values translate into 
happier, more productive workplaces which report high retention rates of skilled staff."

Literature indicates that recognition programmes are instrumental in motivating employees in a competitive business environment with increased management and financial constraints. Coulter (cited in Testa, 2006) found "that a satisfied workforce is a high performance workforce, and a high-performance workforce produces customer satisfaction. In turn, that leads to good financial performance." Flanagan (2005) illustrates this with a case study of a consulting firm, which reported that its key performance improvement goals were exceeded substantially from implementing a company-wide behaviour-based reward and recognition programme for on-time, on-target and on-budget performance.

Research also shows that recognition for a job well done can have a positive influence on employee morale, commitment, performance and retention, which in turn may achieve organisational effectiveness. "Organisational behaviour theory suggests that recognising good performance motivates and reinforces behaviours that are viewed positively by the organisation. and contribute to achieving business objectives." (Mercer. HR Consulting, 2002).

\section{Linking Recognition and Rewards with Business Strategl}

Literature highlights the need to design a recognition programme/policy that is linked to the overall business goals and objectives, which is primarily designed to compliment the organisational culture and other human resource initiatives (Mercer HR Consulting, 2002).

Recognition programmes make up part of an organisations strategic reward system, which can "enable individuals to complete work tasks that are aligned with organisational goals, structures and strategies" (Hartel. Fujimoto, Strybosch \& Fitzpatrick, 2007: 370)

There is also a critical link between performance and recognition as a tool for motivating and retaining employees. It was found that if recognition is not linked to performance it has no purpose or meaning. thus the effectiveness of the programme can be reduced (Jeffries. 1997).

There are a number of considerations for an effective incentive programme which include, quantifying business goals at the employee level and establishing exactly what behaviour is expected of employees to earn a reward (O'Malley, 2006). This may differ across business sections and departments. O'Malley (2006) found that "many companies are finding that a "one-size-fits-all" approach often is not the best course of action when it comes to developing an incentive programme for different levels of achievers and different staff functions."

\section{Tipes of Recognition and Rewards Programmes}

Examples of recognition programmes highlighted in literature, show that informal types are gaining popularity. Wallsten (1998) states that "these focus on spontaneous, sincere and personal appreciation of employee efforts and can successfully recognise employees and the jobs they do while usually requiring little or no funding to implement and maintain." These programmes therefore demonstrate clear advantages for both the organisation and the employee.

Informal recognition programmes can vary depending on the organisations needs and mainly focus on the employee being recognised as the qualifying act occurs. For example, Amor (cited in McKibbin-Brown, 2003) discusses a points program that Xerox Canada has implemented where employees can earn points on specific measurements, such as attendance or furthering their education. These points can then be redeemed from a gift catalogue periodically.

On the other hand, as demonstrated in literature on recognition programmes (mainly in America), some companies still prefer the more traditional and formal programs of recognition. These include "employee of the month" and annual service awards which are generally highly structured and implemented by a timetable (Wallsten, 1998). Whilst these programmes obviously still have a place within certain organisations for meeting specific goals there are many disadvantages related to them as a tool for motivating employees. This is because the very nature of them tends to create competitions and therefore only recognises a small percentage of the workforce, which can be de-motivating to the majority (Glasscock \& Gram, 1995). They are also typically infrequent and impersonal which can do little to make an employee feel valued.

Formal recognition programmes are also mainly public in nature, which James (cited in Matthews, 2006) states that "there will always be some staff who would rather cut out their own tongue than be named at an awards ceremony. which is hardly a motivating experience for them."

McKibbin-Brown (2003) highlights the need for today's recognition programmes to consider the fact that employees no longer stay with one employer for extended periods. Therefore traditional-long service awards may not be as effective as they once were.

The current trend appears to be moving toward adding informal recognition systems to formal programmes, as informal types are typically highly individualised (Wallsten, 1998). Abbot (2004: 21 ) found that employees (in three New Zealand organisations that featured in the 2003 Unlimited Best Places to Work) "all enjoy awards ceremonies, where achievement is publicly announced and celebrated. Often, however, it's the small scale recognition in a comment by a manager that makes an employee feel that he or she is valued."

Recognition programmes can be team-based or individual. Research shows that many organisations cater for both depending on the organisational objectives and the nature of the work. For example, if you want to promote teamwork then you've got to recognise the team as a whole (Lawler cited in Braham, 1989). 


\section{Types of Recognition Rewards}

Recognition is mainly about rewarding individuals/workgroups for what they do above and beyond the requirements of their job to get the best effort from them. It was found that providing recognition is not just about monetary rewards, as this is generally provided to employees as compensation for undertaking the job that they're hired to do. Jeffries (1997: 9) found from extensive data collected that individuals "prefer specific day to day recognition of their contributions over a raise or bonus."

The literature shows that more companies are using intrinsic rewards such as recognition and the opportunity to grow and learn and to advance as key motivators. "Non-financial rewards are being used increasingly by organisations as a low-cost/high value form of recognising high-performing employees" (Mercer Human Resource Consulting, 2004).

On the contrary, Glasscock and Gram (1995) outline that cash (financial) rewards generally don't portray sincere appreciation and thought and can therefore be demotivating to the employee. It was also found that organisations do not get the best effort from employees by paying them more. "For employees who just want more money, they'll never be satisfied with what they're paid. Their expectations will always rise with each salary increase." (Nelson, 1996: 68).

Therefore, there is a focus on non-financial rewards, which many authors see as becoming increasingly popular for providing recognition in the future. This is because as companies become more competitive they will not be able to afford to provide high value economic rewards and they will look more at creative intrinsic rewards that allow it to attract and retain the best people.

Research indicates that the greatest reward an individual can receive is the acknowledgement that they did contribute to making something meaningful happen. "When individuals find satisfaction in the work itself, they appreciate all types of feedback because it helps them do a better job" (Richardson, 2003). It was found from surveys undertaken over a 60 year period with consistent results that one of the top three things employees wanted from their jobs was full appreciation for work done (Richardson, 2003).

It was also indicated in the literature findings that that there is a shift in what people are wanting as rewards, due to changing lifestyles. Rabaut (cited in Braham, 1989) states "companies must understand their employees and their motivation. This might be flexitime for one employee, while for another it might be having three months off." Therefore, managers must understand that today's workforce (particularly Generation Xers) responds positively to more than financial motivation (Jeffries, 1997).

Rewards should also fit the personality and demographics of the employee being honoured whenever possible for it to be meaningful to an individual. "In our experience, employees prefer a choice of rewards that have varying appeals, depending on their life, stage, age and gender" (O’Malley, 2006).

Research undertaken by Mercer HR Consulting (2002) throughout Australasia, found that approximately $80 \%$ of organisation's researched use non-financial rewards with the aim to both motivate employees and to thank them for achieving a specific goal and around $50 \%$ use them as a retention tool. Of the organisations that assess the effectiveness of non-financial rewards, the majority find that they are an effective means of achieving desired outcomes.

\section{Designing a Recognition and Rewards Programme}

The literature outlines that recognition can be a powerful tool for achieving company goals and changing the methods, behaviours and practices used to reach them if the programme is designed properly. Glasscock and Gram (1995) identify recognition as the act of acknowledgement, appreciation and approval (the $3 \mathrm{~A}$ 's). To develop tools, techniques and practices that deliver the 3 A's an organisation must design a programme that is easy to manage (administratively) and work within the scope of the budget. It must also be driven from the top and be ongoing (given on a frequent basis). Top management needs to actively use recognition and also encourage their managers to do so. It is also important to educate both managers and employees on the benefits and importance of recognition and highlight techniques that managers can use to provide recognition. Glasscock and Gram (1995) outline the following five steps for developing an effective recognition system:

- Determine what you want to achieve: vision, mission, strategy, goals and objectives

- Determine what behaviours, practices, and activities will support the things you want to achieve.

- Select your tools to deliver recognition for the above practices. For example, vouchers, thank you cards.

- Recognise behaviours and practices whenever they are exhibited.

- Measure, monitor and continuously improve the recognition processes.

It is also recommend that each step of the design process is communicated to everyone involved, both managers and employees. It should also be viewed as a long-term commitment rather than a short-term fix.

\section{Implementing a Recognition and Rewards Programme}

The key themes throughout the literature relating to the successful implementation of a recognition programme are best portrayed by Glasscock and Gram (1995), which identify the following criteria for establishing tools and methods for recognition: 
Sincerity - every behaviour that the organisation wants to see is reinforced through sincere appreciation.

Fairness and consistency - an organisation should list the behaviours and activities (objective criteria) that best serve achieving its business goals then give everyone the responsibility of initiating recognition when these behaviours or activities occur.

Timeliness - recognition should be given as close as possible to the performance being acknowledged. "Research shows that rewards that come weeks or months after the fact do little to encourage higher levels of performance" (Mercer HR Consulting, 2002).

Frequency- Saying "thanks" and showing appreciation for those behaviours and practices that support business success should happen at the time the behaviour or practice occurs.

Flexibility - Offering a varicty of methods for receiving recognition to ensure that the recipient's needs are met. This involves matching the reward to the person, as it is important for employees to place a value on the reward (Mercer HR Consulting. 2002).

Appropriateness - The recognition method selected should match the effort expended, the behaviour exemplified, or the results achieved. All good performance should be recognised but in varying degrees (proportional) (Jeffries, 1997). Effective rewards are designed to account for the significance of the contribution or achievement (Mercer HR Consulting, 2002).

Specific - Recipients should know exactly what they are being thanked for and why their contribution is valuable.

\section{Methodology}

An initial literature search was undertaken to determine, amongst other things, current approaches towards the design and implementation of recognition programmes. Further to the literature search a survey questionnaire was then developed to assess aspects such as managers across the organisation's use of. pereeived effectiveness and potential barriers in relation to the existing programme, as well as requesting them to rank the existing types and circumstances for which recognition and rewards were provided. The survey was emailed in September 2004 to all 32 managers across the sites different business sections. A response rate of $72^{\circ} \%(n=23)$ was achieved. It was decided that the most effective way of obtaining employee input was to conduct two focus groups of approximately 12 employees each. Each of the managers surveyed were requested to recommend two employees that they felt would be able to provide an objective, rational and meaningful contribution to the focus group discussions. Approximately 40 names were put forward by the managers, of which 24 employees representing a cross section of departments and positions were selected to attend the focus groups, which were held in October 2004. As part of the focus group sessions employees were also requested to indicate and rank the circumstances and types of recognition and rewards that they felt were warranted.

Based on the information obtained from the literature research, together with the management and employee surveys, recommendations were put forward to senior management to implement a revised recognition framework, which included objectives, processes, criteria and guidelines for implementation.

At approximately the same time a bi-annual site culture survey was undertaken in December 2004 and the results further highlighted a low perception amongst employees of recognition and rewards. To obtain a more specific perspective on this issue it was decided that employees would again be surveyed. For this purpose a new questionnaire was developed and administered in September 2005. Employees across the business's different departments were requested to rate the degree to which they agreed the key rewards and recognition dimensions of performance (five variables), leadership guidance and support (seven variables), rewards (three variables) and recognition (five variables) applied to the existing system. A scale of 1 to 5 was used to allow respondents to indicate the degree to which they agreed with 20 statements covering the variables, where ' 1 ' was strongly disagree, ' 2 ' was disagree, ' 3 ' neutral, ' 4 ' agree and ' 5 ' was 'strongly agree'.

Based on the results of this survey together with previous findings, it was decided to implement a revised recognition/reward system in October 2005. This was based on the original recommendations submitted to senior management and incorporated the key aspects of informal, discretionary recognition outlined within the company's existing human resources policies. The system that was actually adopted was slightly modified from the original recommendations and condensed into a two page document, which outlined key criteria for providing recognition and rewards as highlighted by Glasscock and Gram (1995) in the literature review. The system also outlined the four main key result areas of the business and provided examples of employee behaviours that contribute towards these. To maintain consistency and promote desired employee behaviours across the organisation a qualification guideline table was included. The table specified four levels of recognition based on qualifying behaviours (such as contribution towards the key result areas and significance of the outcome), as well as circumstances and types of recognition/reward that coincided with each level. Along with formal communication of the new system, a goal of improved recognition was also incorporated into departmental manager's performance improvement plans.

To assess if perceived recognition had improved and the effectiveness of the new programme employees were surveyed approximately six months post implementation of the revised recognition/rewards system in April 2006 using the same questionnaire. If successful, the programme would be considered for incorporating into company human resources policies and introducing it across the entire business. For the initial survey 
conducted in September 2005 a response rate of $59 \%$ $(\mathrm{n}=151)$ was achieved from a representative sample of 258 employees and in April 2006 after the new system was introduced 192 staff members $(78 \%)$ across the different business units responded.

This data was coded, entered and analysed using the SPSS statistics package.

\section{Results and Discussion}

\section{Management Demographics}

Of the 23 managers who responded to the initial research in September 2004, before changes to the existing system were recommended and implemented, 12 of the respondents were concentrated in the operations areas $(52 \%)$, that also had the highest number of staff reports (one had more than 150 staff reports, four had between 100 and 149 staff reports and two had between 50 and 99 staff reports). This was followed by managers of support services such as human resources, marketing and finance $(26 \%)$ and other departments $(22 \%)$ who tended to have 29 or less staff reports. These respondents can be regarded as representative of the different departments, as are the number of staff reports. Ten respondents $(44 \%)$ frequently used the formal awards system, $22 \%$ used them sometimes and the remainder (34\%) never used them at all. Furthermore, of those using the policy $86 \%$ found them to be effective whilst $14 \%$ did not find them effective.
Additional aspects considered were factors which prevented managers from giving recognition in circumstances where they would have liked to. Budget constraints were cited as the main reason by most managers $(43 \%)$. This was followed by uncertainty, inconsistencies and internal competition regarding implementation $(33 \%)$, policy constraints $(19 \%)$ and time constraints $(5 \%)$. Results are summarised in Table 1.

On the one hand the frequency of use and high level of effectiveness of the awards is very positive. However, causes for concern are that approximately one third of respondents never use the awards programme and a large percentage of respondents feel hampered by aspects such as budgetary constraints. Given the high levels of effectiveness of the recognition awards, the opportunities in designing, implementing and communicating an appropriate programme holds many advantages.

\section{Circumstances for Providing Recognition and Rewards}

Managers and employees surveyed in September 2004 were also requested to rank in order of priority the circumstances for providing recognition. The results indicate that the majority of the circumstances for providing recognition between managers and employees showed fairly similar rankings, with six of the nine items showing differences in rankings of two or less. However, relatively marked differences occur between the two groupings in relation to the issue of 'working unusually long hours', for both individuals and teams, with managers ranking this aspect far higher than employees. Table 2 provides a summary of results.

Table 1: Managerial survey of current recognition policy.

\begin{tabular}{|c|c|c|c|}
\hline \multicolumn{2}{|c|}{ DEPARTMENTAL MANAGERS DEMOGRAPHICS } & $\mathrm{N}$ & $\%$ \\
\hline Department: & $\begin{array}{l}\text { Operations } \\
\text { Support } \\
\text { Other }\end{array}$ & $\begin{array}{r}12 \\
6 \\
5\end{array}$ & $\begin{array}{l}52 \\
26 \\
22\end{array}$ \\
\hline Staff Reports: & $\begin{array}{c}150 \text { or more } \\
100-149 \\
99-50 \\
49-30 \\
29-10 \\
9 \text { or less }\end{array}$ & $\begin{array}{l}1 \\
6 \\
3 \\
1 \\
6 \\
6\end{array}$ & $\begin{array}{r}4 \\
26 \\
14 \\
4 \\
26 \\
26\end{array}$ \\
\hline Use of Recognition Awards: & $\begin{array}{l}\text { Frequently } \\
\text { Sometimes } \\
\text { Never }\end{array}$ & $\begin{array}{r}10 \\
5 \\
8\end{array}$ & $\begin{array}{l}44 \\
22 \\
34\end{array}$ \\
\hline Effectiveness of Recognition Awards: & $\begin{array}{l}\text { Effective } \\
\text { Ineffective }\end{array}$ & $\begin{array}{r}13 \\
2 \\
\end{array}$ & $\begin{array}{l}86 \\
14\end{array}$ \\
\hline Barriers to Providing Recognition: & $\begin{array}{l}\text { Budget constraints } \\
\text { Uncertainty, inconsistencies } \\
\text { Policy constraints } \\
\text { Time constraints }\end{array}$ & $\begin{array}{r}10 \\
8 \\
4 \\
1\end{array}$ & $\begin{array}{l}43 \\
33 \\
19 \\
5\end{array}$ \\
\hline
\end{tabular}


Table 2: Managers and employees circumstances for providing recognition rewards.

\begin{tabular}{|l|c|c|c|}
\hline CIRCUMSTANCES & Managers Ranking & $\begin{array}{c}\text { Employees } \\
\text { Ranking }\end{array}$ & Ranking Difference \\
\hline Development of new ideas by individuals & 1 & 3 & 2 \\
\hline Individual 'going the extra mile' & 2 & 1 & 1 \\
\hline Individual working unusually long hours & 2 & 8 & 6 \\
\hline Team working unusually long hours & 2 & 9 & 7 \\
\hline Excellent performance on project by individual & 5 & 5 & 0 \\
\hline Exceeding individual targets & 5 & 4 & 1 \\
\hline Exceeding team targets & 5 & 2 & 3 \\
\hline Meeting individual targets & 8 & 7 & 1 \\
\hline Meeting team targets & 8 & 6 & 2 \\
\hline
\end{tabular}

Whilst the similarities in rankings for the majority of circumstances would indicate that this is positive in terms of reaching consensus for providing recognition between the parties, the significant differences in relation to 'working long hours' needs to be addressed. Perhaps management has an expectation that employees put in extra time, which would be recognised, whilst employees are of the opinion that extra hours possibly require additional financial rewards over and above the standard ones provided. It could also be that employees are not that willing to put in extra hours over and above their "normal" working day. The causes of the relatively marked differences for 'working long hours' needs to be clarified so that the issue can be addressed.

\section{Types of Recognition and Rerrards}

The results from the September 2004 surveys show that the majority of the differences between managers and employees in terms of ranking the types of recognition rewards preferred indicated, for the most part, slight to no differences. In this respect, 12 of the 19 items showed differences in rankings of three or less.

However, noticeable differences occur in the rankings management and employees allocated for "public announcements' ('2' and ' 11 ' respectively), 'restaurant vouchers' ('10' and '4'), 'discounted/free company products' ('12' and '17') and 'movie tickets' ('17' and ' 6 ' respectively). In addition, three of the recognition preferences indicate moderate differences of ' 4 ' in rankings. Full details are shown in Table 3.

Although management view 'public announcement of achievement' highly ('2'), and possibly see it as a way of formally publicising, communicating and recognising achievement, which could serve as a motivator to others, it would appear that employees prefer more low-key individual recognition. It is also interesting to note that

Table 3: Managers and employees preferred types of recognition rewards.

\begin{tabular}{|l|c|c|c|}
\hline TYPE OF RECOGNITION REW ARD & $\begin{array}{c}\text { Managerial } \\
\text { Ranking }\end{array}$ & Employee Ranking & Ranking Difference \\
\hline On the spot 'thank you's & 1 & 2 & 1 \\
\hline Public announcement of achievement & 2 & 11 & 9 \\
\hline Gift vouchers & 3 & 3 & 0 \\
\hline Lunches/BBQ's & 4 & 5 & 1 \\
\hline Extra paid leave & 4 & 1 & 3 \\
\hline Opportunity to undertake interesting projects & 4 & 8 & 2 \\
\hline Opportunity to undertake training & 7 & 9 & 1 \\
\hline Letter of thanks & 8 & 7 & 4 \\
\hline Opportunity to attend conferences & 8 & 12 & 6 \\
\hline Restaurant vouchers & 10 & 4 & 4 \\
\hline Higher duties & 10 & 14 & 5 \\
\hline Discounted/free company products & 12 & 17 & 1 \\
\hline Branded goods/merchandise & 12 & 10 & 1 \\
\hline Recognition in company publications & 12 & 13 & 3 \\
\hline Participation in working groups & 15 & 16 & 1 \\
\hline Nominations for company awards & 16 & 19 & 11 \\
\hline Certificates/plaques & 17 & 18 & 2 \\
\hline Movic tickets & 17 & 6 & 15 \\
\hline Nomination for industry or professional award & 17 & & \\
\hline
\end{tabular}


employees rank related types of formal, public recognition such as 'recognition in company publications' ('13'), 'nominations for company awards' ('19') and 'certificates/plaques' ('18') at the lower end of the rankings. James, as cited in Matthews (2006) outlines the potential disadvantages of recognition which is public in nature and which can be de-motivating, perceived as structured and staged, rather than spontaneous, and even viewed as patronising. Furthermore, 'restaurant vouchers' and 'movie tickets', rank substantially higher for employees, whilst the similar item of 'gift vouchers' ranks equally as high with both groups (' 3 '). It could indicate that employees view 'gift vouchers' as analogous to 'restaurant vouchers' and 'movie tickets', whilst managers see these as different types of recognition. It should also be mentioned that 'gift vouchers' typically have a $\$ 20$ value attached to them, whilst that of 'restaurant vouchers' and 'movie tickets' is $\$ 50$ for each.

The lower ranking ('17') allocated for 'discounted/free products' by employees when compared with that of managers ('12') could possibly be because employees view this form of recognition as a "right", given that the organisation, and by implication they themselves produce the products. If this is the case, perhaps employees need to understand the difference between what they feel they are entitled to and what is regarded as recognition and rewards attached to performance.

When considering the types of recognition and rewards to provide it is worth noting the trends towards increasing informal approaches, which are spontaneous, perceived as fair and which require little or no funding (Bell, 2004; Mercer, 2002; Wallsten, 1998).

\section{5/2006 Survey Results}

When comparing the results of the 2005 and 2006 employee surveys for the 20 performance, leadership support, rewards and recognition variables it was found that 16 variables showed an increase in mean values, whilst four variables indicated a very slight decrease in 2006. Except for one variable, 'pay and benefits are satisfying', all the other 19 variables for both 2005 and 2006 have mean scores of ' 3 ' or more, of which 10 variables mean values are more than ' $3.5^{\prime}$ '. It is also interesting to note that the 'performance' related variables are the only ones which are all above ' 3.5 '. A study conducted by Flanagan (2005) illustrates the positive effect that organisation wide recognition and rewards programmes can have on performance. This link is supported by Jeffries (1997). See Table 4 for a full analysis of results.

Table 4: Mean comparisons of variables by year.

\begin{tabular}{|c|c|c|c|c|}
\hline VARIABLES & $\begin{array}{c}2005 \text { Mean } \\
(\mathrm{n}=151)\end{array}$ & $\begin{array}{c}2006 \\
(n=192)\end{array}$ & F-value & P-value \\
\hline $\begin{array}{l}\text { PERFORMANCE: } \\
\text { Go the extra mile } \\
\text { Worthwhile working hard } \\
\text { Encouraged to do my best } \\
\text { Know what is expected } \\
\text { Strive to exceed goals }\end{array}$ & $\begin{array}{l}3.72 \\
3.53 \\
3.72 \\
3.68 \\
3.74\end{array}$ & $\begin{array}{l}3.78 \\
3.77 \\
3.78 \\
3.75 \\
3.79\end{array}$ & $\begin{array}{l}0.426 \\
4.817 \\
0.260 \\
0.376 \\
0.235\end{array}$ & $\begin{array}{l}0.515 \\
0.029 \\
0.611 \\
0.540 \\
0.628\end{array}$ \\
\hline $\begin{array}{l}\text { LEADERSHIP SUPORT/DIRECTION: } \\
\text { Informed about goals } \\
\text { Leader/manager encourages me } \\
\text { Leader/manager expectations known } \\
\text { Receptive to new ideas } \\
\text { Encouraged to think of new ideas } \\
\text { Supported to make improvements } \\
\text { Clear how I can contribute to goals }\end{array}$ & $\begin{array}{l}3.20 \\
3.00 \\
3.86 \\
3.29 \\
3.07 \\
3.22 \\
4.06 \\
\end{array}$ & $\begin{array}{l}3.21 \\
3.22 \\
3.84 \\
3.30 \\
3.19 \\
3.40 \\
4.12\end{array}$ & $\begin{array}{l}0.007 \\
5.369 \\
0.068 \\
0.016 \\
0.984 \\
3.521 \\
0.538\end{array}$ & $\begin{array}{l}0.935 \\
0.021 \\
0.794 \\
0.901 \\
0.322 \\
0.061 \\
0.464\end{array}$ \\
\hline $\begin{array}{l}\text { REWARDS: } \\
\text { Pay and benefits are satisfying } \\
\text { Opportunities for growth/advancement } \\
\text { Incentives for exceptional effort }\end{array}$ & $\begin{array}{l}2.82 \\
3.52 \\
3.93 \\
\end{array}$ & $\begin{array}{l}2.95 \\
3.65 \\
4.06 \\
\end{array}$ & $\begin{array}{l}1.096 \\
1.494 \\
2.164 \\
\end{array}$ & $\begin{array}{l}0.296 \\
0.222 \\
0.142 \\
\end{array}$ \\
\hline $\begin{array}{l}\text { RECOGNITION: } \\
\text { Recognition for suggestions/ideas } \\
\text { Effort, superior performance recognised } \\
\text { Team leader recognises efforts } \\
\text { Understand which efforts are recognised } \\
\text { Provide recognition to colleagues }\end{array}$ & $\begin{array}{l}3.33 \\
3.46 \\
3.93 \\
3.44 \\
3.17 \\
\end{array}$ & $\begin{array}{l}3.44 \\
3.44 \\
3.92 \\
3.61 \\
3.01\end{array}$ & $\begin{array}{r}1.117 \\
0.026 \\
0.040 \\
2.433 \\
1 \mathrm{~L} 817\end{array}$ & $\begin{array}{l}0.291 \\
0.873 \\
0.841 \\
0.120 \\
0.178\end{array}$ \\
\hline
\end{tabular}


The results in Table 4 also indicate that for the variables 'worthwhile working hard', 'leader/manager encourages me' and 'supported to make improvements' significant differences $(\mathrm{F}=4.817, \mathrm{P}=0.029 ; \mathrm{F}=5.369$, $\mathrm{P}=0.021$ and $\mathrm{F}=3.521, \mathrm{P}=0.061$ respectively) exist between the years 2005 and 2006. The mean differences in scores for these variables for 2005 and 2006 tend to underpin these significant differences. It is interesting to note that within six months two variables of the 'leadership' component have already shown significant improvements.

For the 'rewards' component two of the variables for both years, namely 'opportunities for growth/advancement' and 'incentives for exceptional effort', have mean scores of more than 3.5, whilst the 'pay and benefits' variable is below three. These results need to be viewed against the background of the important role of pay as a motivator and its link to performance, as well as a total approach towards rewards which includes aspects such as pay, benefits. incentives and opportunities for advancement. The importance of employees in understanding these interactions should thus not be overlooked.

\section{Departmental Comparisons}

The mean scores for the different departments are consistent with the mean scores for the different years as set out in Table 4. For example, also except for one variable. 'pay and benefits are satisfying', all the other 19 variables across the departments have mean scores of ' 3 ' or more, with nine variables, including all the performance variables once again, having mean values more than ' $3.5^{\prime}$ (see Table 5). It is also interesting to note that for the variable of "pay and benefits satisfying', seven of the nine departments rated this below ' 3 ', whilst factory management rate this variable at $3.83^{\circ}$ and it is close to being significant $(\mathrm{P}=0.163)$.

The results in Table 5 also show that significant differences occur between departments in relation to the variables of 'go the extra mile' ( $\mathrm{F}=2.187$, $\mathrm{P}=0.044)$. 'supported to make improvements' $(\mathrm{F}=3.078, \mathrm{P}=0.006)$ and clear how I can contribute to goals' $(F=2.122$. $P=0.050)$. The differences in mean scores for these variables across the different departments support these significant differences. In this respect it is also interesting to note the relatively higher scores that factory management place on most of the variables, although the sample size is small $(n=6)$. As highlighted by O'Malley (2006) organisations are finding that a "one size fits all" approach often does not work and it is thus important that organisations are conscious of this when designing and implementing a recognition and rewards programme. However, whilst flexibility is an important criteria for a programme, so are criteria such as fairness, consistency and appropriateness (Glasscock \& Gram, 1995).

\section{Conclusion}

Based on the research and survey findings the organisation designed and implemented a revised recognition and rewards system linked to the organisations strategy that would hopefully assist in improving staff motivation and morale, lead to increased performance and in turn organisational effectiveness.

Findings from the initial management survey, prior to changes to the existing programme being introduced, indicated a high level of usage amongst respondents and the effectiveness of recognition awards was rated very highly by those who use them. However, barriers such as budget and policy constraints, as well as uncertainty regarding implementation were regarded as problematic. Given that the organisation has since included aspects such as guidelines for implementation, specific criteria for allocating recognition and rewards, as well as budget allocations of a relatively low value as part of the revised programme, this should hopefully lead to increased usage and effectiveness and assist in reducing potential barriers to successful implementation.

The results of the study also indicate that insofar as the circumstances for providing recognition and rewards is concerned, together with the types of recognition rewards allocated, that managers and employees are to a large extent in close agreement regarding these aspects. These areas of common ground can assist in reaching consensus when decisions regarding circumstances and types of recognition rewards are made. However, fairly marked differences between these two groupings exist in regard to aspects such as 'working unusually long hours' and managements preference for public types of recognition as opposed to employees favouring tangible, fairly low dollar value, tangible, individual types of rewards such as 'movic tickets'. These aspects need to be discussed further and clarified in order to ensure that mutual understanding in these areas is reached.

The relatively high ratings for the performance related variables for both the 2005 and 2006 surveys, as well as the findings for these variables across the departments is positive when viewed against the background of aspects such as the linkages between recognition, rewards and performance, as well as the "performance culture" of the organisation. The majority of the other recognition and rewards variables also show increases across the departments during the six month period between the two surveys, which is an indication that the organisation is on the right track in regards to the revised programme.

Insofar as the 'pay and benefits are satisfying' variable that rates lower than the other 19 variables is concerned, it should be mentioned that the organisation is recognised as providing rewards above the industry average in relation to benchmark organisations and the organisation should possibly take action in communicating this message more effectively, together with creating an understanding of a "total" approach taken towards providing recognition and rewards. 


\begin{tabular}{|c|c|c|c|c|c|c|c|c|c|}
\hline VARIABLES & 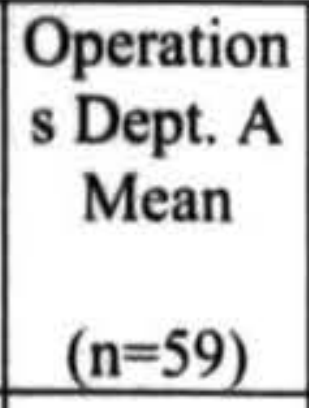 & $\begin{array}{l}\text { Operat. } \\
\text { Dept. B } \\
\text { Mean } \\
(n=106)\end{array}$ & $\begin{array}{l}\text { Operat. } \\
\text { Dept. C } \\
\text { Mean } \\
\\
(n=53)\end{array}$ & $\begin{array}{c}\text { Operat. } \\
\text { Dept. D } \\
\text { Mean } \\
\\
(n=24)\end{array}$ & $\begin{array}{l}\text { Operat. } \\
\text { Dept. E } \\
\text { Mean } \\
(\mathrm{n}=55)\end{array}$ & $\begin{array}{l}\text { Support } \\
\text { Depts. } \\
\text { Mean } \\
\\
(n=40)\end{array}$ & \begin{tabular}{|c|} 
Factory \\
Managem \\
ent \\
Mean \\
$(\mathrm{n}=6)$ \\
\end{tabular} & $\begin{array}{c}\text { F- } \\
\text { Value }\end{array}$ & $\begin{array}{c}\text { P- } \\
\text { Value }\end{array}$ \\
\hline \multicolumn{10}{|l|}{ PERFORMANCE: } \\
\hline Go the extra mile & 3.73 & 3.66 & 3.68 & 3.96 & 3.85 & 3.75 & 5.00 & 2.187 & 0.044 \\
\hline $\begin{array}{l}\text { Worthwhile } \\
\text { working hard }\end{array}$ & 3.63 & 3.50 & 3.75 & 4.08 & 3.76 & 3.65 & 3.83 & 1.382 & 0.221 \\
\hline $\begin{array}{l}\text { Encouraged to do } \\
\text { my best }\end{array}$ & 3.83 & 3.62 & 3.79 & 3.71 & 3.84 & 3.80 & 4.33 & 0.658 & 0.684 \\
\hline $\begin{array}{l}\text { Know what is } \\
\text { expected }\end{array}$ & 3.71 & 3.63 & 3.81 & 3.63 & 3.83 & 3.69 & 4.33 & 0.727 & 0.628 \\
\hline $\begin{array}{l}\text { Strive to exceed } \\
\text { goals }\end{array}$ & 3.76 & 3.68 & 3.85 & 3.75 & 3.81 & 3.80 & 4.33 & 0.677 & 0.669 \\
\hline $\begin{array}{l}\text { LEADERSHIP } \\
\text { SUPPORT/ } \\
\text { DIRECTION: } \\
\text { Informed about } \\
\text { goals }\end{array}$ & 3.00 & 3.28 & 3.13 & 3.42 & 3.34 & 3.23 & 3.83 & 1.317 & 0.249 \\
\hline $\begin{array}{l}\text { Leader/manager } \\
\text { encourages me }\end{array}$ & 3.00 & 3.00 & 3.17 & 3.17 & 3.25 & 3.34 & 3.33 & 1.197 & 0.307 \\
\hline $\begin{array}{l}\text { Leader/manager } \\
\text { expectations known }\end{array}$ & 3.88 & 3.81 & 3.81 & 3.92 & 3.87 & 3.84 & 4.17 & 0.294 & 0.940 \\
\hline $\begin{array}{l}\text { Receptive to new } \\
\text { ideas }\end{array}$ & 3.31 & 3.14 & 3.45 & 3.08 & 3.35 & 3.35 & 4.00 & 1.270 & 0.270 \\
\hline $\begin{array}{l}\text { Encouraged to think } \\
\text { of new ideas }\end{array}$ & 3.03 & 3.00 & 3.04 & 3.33 & 3.35 & 3.38 & 3.83 & 1.661 & 0.130 \\
\hline $\begin{array}{l}\text { Supported to make } \\
\text { improvements }\end{array}$ & 3.02 & 3.36 & 3.60 & 3.00 & 3.47 & 3.35 & 3.67 & 3.078 & 0.006 \\
\hline $\begin{array}{l}\text { Clear how I can } \\
\text { contribute to goals }\end{array}$ & 3.95 & 4.16 & 4.19 & 4.08 & 4.22 & 3.80 & 4.33 & 2.122 & 0.050 \\
\hline \multicolumn{10}{|l|}{ REWARDS: } \\
\hline $\begin{array}{l}\text { Pay and benefits are } \\
\text { satisfying }\end{array}$ & 2.69 & 2.80 & 3.09 & 2.71 & 2.96 & 2.97 & 3.83 & 1.545 & 0.163 \\
\hline $\begin{array}{l}\text { Opportunities for } \\
\text { growth/advancemen }\end{array}$ & 3.59 & 3.45 & 3.45 & 3.88 & 3.64 & 3.70 & 4.00 & 0.886 & 0.505 \\
\hline $\begin{array}{l}\text { Incentives for } \\
\text { exceptional effort }\end{array}$ & 3.97 & 3.91 & 4.04 & 4.25 & 4.09 & 3.85 & 4.33 & 1.049 & 0.394 \\
\hline \multicolumn{10}{|l|}{ RECOGNITION: } \\
\hline $\begin{array}{l}\text { Recognition for } \\
\text { suggestions/ideas } \\
\text { Effort, superior }\end{array}$ & 3.32 & 3.35 & 3.38 & 3.29 & 3.62 & 3.43 & 3.83 & 0.803 & 0.568 \\
\hline $\begin{array}{l}\text { performance } \\
\text { recognised }\end{array}$ & 3.36 & 3.50 & 3.47 & 3.42 & 3.40 & 3.28 & 4.00 & 0.559 & 0.703 \\
\hline $\begin{array}{l}\text { Team leader } \\
\text { recognises efforts } \\
\text { Understand which }\end{array}$ & 3.80 & 3.90 & 3.96 & 3.88 & 3.96 & 3.95 & 4.50 & 0.813 & 0.561 \\
\hline $\begin{array}{l}\text { Understand which } \\
\text { efforts are } \\
\text { recognised }\end{array}$ & 3.39 & 3.45 & 3.53 & 3.79 & 3.67 & 3.65 & 4.33 & 1.463 & 0.190 \\
\hline $\begin{array}{l}\text { Provide recognition } \\
\text { to colleagues }\end{array}$ & 3.07 & 3.02 & 3.15 & 2.71 & 3.18 & 3.20 & 3.50 & 0.811 & 0.562 \\
\hline
\end{tabular}


In conclusion, the organisation has decided to go down the path of reviewing its existing recognition and rewards system after a fairly extensive research process and the initial survey results are promising. Through continuous monitoring and evaluation of the recognition and rewards programme and ensuring that it is linked to the organisations strategic business goals, meets certain key criteria such as fairness, consistency and flexibility, whilst including formal and informal approaches towards recognition and rewards, should result in employee satisfaction, increasing performance and organisational effectiveness.

Maintaining and improving the recognition and rewards system provides the organisation with both ongoing opportunities and challenges.

\section{Future Research}

It is recommended that further research is conducted approximately one year after the last survey was conducted in May 2006 in order to determine whether the revised programme and the assessment of the variables indicate any significant changes and if so what these changes are.

At the same time this could be an opportunity to obtain a richer data set and to, for example, obtain employee biographical information such as age, length of service, gender and level in the organisation in order to make possible comparisons between the variables in relation to biographical characteristics as well. A larger, more representative sample of management should also be included in future studies. This research could also provide an opportunity for a graduate student required to conduct an industry based project to progress further.

\section{References}

Abbot, L. (2004). Building great workplaces. Employment Todar; 20-21.

Bell, M. (2004, April/May). Just rewards. Employment Todar, 14-16.

Braham, J. (1989). A rewarding place to work. Industr7. Week. 238, 18.

Bursch, J. (1999). Well-structured employee reward/recognition programs yield positive results. HR Focus, 76, 11.

Flanagan, W. (2005). The best incentive programs of 2005. Incentive, 179, 12.

Glasscock, S. and Gram, K. (1995). Winning ways: Establishing an effective workplace recognition system. National Productivity Review; 14(3), 91102.

Hartel, C., Fujimoto, Y., Strybosch, V. and Fitzpatrick, K. (2007). Human Resource
Management.

Transforming Theory into Innovative Practice. Australia: Pearson Education.

Jeffries, R. (1997). Reaping the rewards of recognition. HR Focus, 71(1), 9.

McKibbin-Brown, L. (2003). Beyond the gold watch employee recognition today. Workspan. 46(4).

Matthews, V. (2006). Everyone's a winner. Personnel Today.

Mercer Human Resource Consulting. (2004). Perfecting the Performance-Reward Link. Retrieved October 6, 2004. Online: http://www.mercerhr.com.au

Mercer Human Resource Consulting. (2002). Is a thank you too much to ask? Retrieved August 13, 2004. Online: http://www.imercer.com

Nelson, B. (1996). Dump the cash, load on the praise. Personnel Journal, 75(7), 65-70.

O'Malley, S.J. (2006). One size does not fit all: Tailoring incentive programs for all employees. HR Banker: 7(2).

Richardson, M. (2003). Rewards, recognitions that make sense. California CP.A. 71(7).

Stone, R (2002). Human Resource Management - $4^{\text {th }}$ Edition. Milton, Australia: John Wiley \& Sons Ltd.

Testa, B.M. (2006). Rewards relaunch. Workforce Management. $\mathbf{8 5}(8)$.

Wallsten, K. (1998). Targeted rewards have greater value and bigger impact. Workforce. 77(11).

Wiesner, R. and Millett, B. (2003). Human Resource Management, Challenges \& Future Directions. Australia: John Wiley \& Sons Ltd.

\section{Authors}

Jessica Harvey

Human Resources Advisor

Heinz Wattie's Ltd

P.O. Box 439

Hastings

Jessica.Harvey $a$ nz.hjheinz.com

Robbic Field

Lecturer

Faculty of Business and Computing

Eastern Institute of Technology

Private Bag 1201

Taradale

Napier

RField $a$ eit.ac.nz 